\title{
Observations on Shorefast Ice Dynamics in Arctic Alaska and the Responses of the Iñupiat Hunting Community
}

\author{
JOHN C. “CRAIG” GEORGE, ${ }^{1}$ HENRY P. HUNTINGTON,${ }^{2}$ KAREN BREWSTER, ${ }^{3}$ HAJO EICKEN,${ }^{4}$ \\ DAVID W. NORTON ${ }^{5}$ and RICHARD GLENN ${ }^{6}$
}

(Received 19 February 2003; accepted in revised form 1 December 2003)

\begin{abstract}
Although shorefast sea ice forms a platform that facilitates travel, camping, and hunting by Iñupiat subsistence hunters and fishers in the western Arctic, the nearshore sea-ice zone remains an unforgiving and dynamic environment. Traditional hunters constantly hone site-specific experiences and skills with which to optimize the reward-to-risk ratio inherent in operating from this coastal ice. Nearshore ice conditions nevertheless can change suddenly, endangering even the most experienced subsistence hunters. This study examines two (of several) 20th-century events, 40 years apart, in which shorefast ice failed, threatening Iñupiat whale hunters with loss of confidence, livelihood, and life. These events differed in character. In one event, the shorefast ice was "crushed" by moving ice floes. In the other, the shorefast ice broke free of land. Our examination focuses on the relationship of subsistence hunters to the ice, the environmental causes of ice failures, the evolving technology for predicting ice behavior, and the longer-term implications of global change for this system. The complexity of geophysical processes underlying coastal ice behavior makes ice failures unpredictable. Thus, hunters must assume and manage risk. The variable and uncertain environment to which whale hunters are accustomed has produced an inherent flexibility that has helped them adapt to new conditions and will continue to do so in the future.
\end{abstract}

Key words: Iñupiat, sea ice, safety, breakup, calving, shorefast ice, hunting, technology, whaling, Barrow

RÉSUMÉ. Bien que la banquise côtière constitue une plate-forme qui permet aux Iñupiat de l'Arctique de l'Ouest de se déplacer et de camper lorsqu'ils pratiquent la chasse et la pêche de subsistance, la zone de banquise proche du littoral reste un milieu dynamique qui ne pardonne pas. Les chasseurs traditionnels améliorent constamment les habiletés et l'expérience reliées à des sites particuliers, qui leur permettent d'optimiser le rapport récompense-risque inhérent au fait de travailler depuis la glace côtière. Les conditions de cette dernière peuvent toutefois changer brusquement, mettant en danger même les chasseurs de subsistance les plus chevronnés. Cette étude se penche sur deux (parmi plusieurs) épisodes survenus au XX' siècle, à 40 ans d'écart, durant lesquels la banquise côtière s'est rompue, ébranlant la confiance des baleiniers Iñupiat et menaçant leur moyen de subsistance ainsi que leur vie. Ces événements étaient de nature différente. Dans l'un, la glace côtière avait été «écrasée» par des floes en dérive. Dans l'autre, la banquise côtière s'était détachée de la terre ferme. Notre étude se concentre sur le rapport entre les chasseurs de subsistance et la glace, les causes environnementales de la fragilisation de la glace, la technologie mise au point actuellement qui permettrait de prédire le comportement de la glace, et les implications à long terme du changement climatique pour ce système. La complexité des processus géophysiques sous-jacents au comportement de la banquise côtière fait que les ruptures de la banquise sont imprévisibles. Les chasseurs doivent donc assumer le risque et le gérer. L'environnement variable et incertain auquel sont accoutumés les chasseurs de baleine leur a donné une souplesse inhérente qui les a aidés à s'adapter à de nouvelles conditions et continuera de le faire dans l'avenir.

Mots clés: Iñupiat, banquise, sécurité, débâcle, vêlage, banquise côtière, chasse, technologie, chasse à la baleine, Barrow

Traduit pour la revue Arctic par Nésida Loyer.

\section{INTRODUCTION}

Sea ice is a defining characteristic not only of the Arctic, but also of Iñupiat hunting practices in northern Alaska (Nelson, 1969; Stonehouse, 1989). For the hunters, shorefast sea ice provides an essential platform for winter and spring hunting, particularly for the bowhead whale (Balaena mysticetus) during its annual spring migration along the Alaska coast of the Chukchi Sea. Despite its name, the shorefast ice is a dynamic and unstable environ-

\footnotetext{
${ }^{1}$ Department of Wildlife Management, North Slope Borough,P.O. Box 69, Barrow, Alaska 99723, U.S.A.; Craig.George@ @orth-slope.org ${ }^{2} 23834$ The Clearing Dr., Eagle River, Alaska 99577, U.S.A.

${ }^{3}$ Oral History Program, Elmer E. Rasmuson Library, University of Alaska Fairbanks, P.O. Box 756808, Fairbanks, Alaska 99775, U.S.A.

${ }^{4}$ Geophysical Institute, University of Alaska Fairbanks, Fairbanks, Alaska 99775, U.S.A.

${ }^{5}$ Arctic Rim Research, 1749 Red Fox Drive, Fairbanks, Alaska 99709, U.S.A.

${ }^{6}$ Arctic Slope Regional Corporation, P.O. Box 129, Barrow, Alaska 99723, U.S.A.

(C) The Arctic Institute of North America
} 
ment, particularly along its seaward edge (Shapiro, 1976; Reimnitz et al., 1978). Successful hunting depends to a great extent on the hunters' understanding of the ice on which they travel, hunt, and camp (Nelson, 1969). Excessive caution may keep hunters too far from their prey. Disregard for possible movement of the shorefast ice, on the other hand, can lead to stranding, loss of gear, or even death. Because the ice varies greatly from year to year and place to place, and because it is part of an interrelated system of currents, winds, ice structure, and water level, successful hunters require a detailed understanding of a complex set of environmental parameters, and as we will demonstrate, "luck" and stochastic factors are important too (Nelson, 1966, 1982; Hibler, 1986). Despite the hunters' expertise and caution, however, mishaps and accidents do occur.

Shorefast ice is also of considerable interest in the context of sea-ice geophysics. Ice-ocean interaction is affected by shorefast ice, which restricts or attenuates the transfer of momentum from atmosphere to ocean and represents an important constraint for nearshore tidal forcing. That is, if the ice is held in place, as shorefast ice is, the surface ocean circulation changes dramatically. The shorefast ice is furthermore associated with complex thermohaline circulation features both inshore and offshore of the shorefast-ice edge, including effects on the transfer of terrestrial freshwater into the marine system (Dmitrenko et al., 1999; Macdonald, 2000). Interaction of polar pack ice with the shorefast ice is important for icepack dynamics, often resulting in the creation of leads and pressure ridges in the Beaufort Sea (Richter-Menge et al., 2002). In contrast to the Beaufort ice, coastal sea ice in Alaska's northern Chukchi Sea is dominated by a flaw zone or polynya, which extends approximately $100 \mathrm{~km}$ seaward of the outer edge of shorefast ice. Norton and Gaylord (2004, this volume) propose that this zone is distinguished from "true" polar pack ice (particularly in late winter) by consisting of varying extents of open water and small, highly mobile ice floes and pans.

Flaw leads or polynyas that form along the shorefast-ice margin are not just of local significance; they also affect the ventilation of the deeper Arctic Ocean through the formation of dense water masses (Winsor and Chapman, 2002). Coastal ice dynamics leave their mark on shorelines. Shorefast ice helps protect the coastline and nearshore sediments from wave erosion, but it may contribute to sediment transport, for example, during onshore ice-push events (Iñupiaq: ivu; Kovacs and Sodhi, 1980). Thus, shorefast ice affects and can be affected by a wide range of environmental factors, although many of the details are poorly understood scientifically. Iñupiat knowledge of the ice can contribute to scientific understanding in several ways: for example, by identifying the roles of local forces on ice dynamics and, particularly, the ways in which changes in sea ice will affect whale hunters and other ice-dependent hunters.

This paper explores the ways in which sea-ice dynamics affect Iñupiat hunters and how social changes such as modern navigation and communication technology affect Iñupiat use of their sea-ice knowledge. It is based on years of discussions with Iñupiat hunters and our direct experience of over 20 years of camping and conducting research on the shorefast ice. We also draw from formal oral history interviews, from archival research, and from two case studies developed for and discussed during the Barrow Symposium on Sea Ice, held in October-November 2000 (Huntington et al., 2001, 2002; Norton, 2002). In that symposium, Inupiat hunters and sea-ice researchers discussed their respective understandings of the sea-ice environment and its implications for humans. This paper is an outgrowth of the collaborative research and exchange of ideas that characterized the symposium and each of our own research methodologies within Iñupiat communities. We examine two case studies that were developed in detail for the Barrow Symposium, amplified by recent events (2002), which are similar to the second case study (1997).

The first case study examines a catastrophic breakup of shorefast ice in May 1957, and the second a large calving event in May 1997 that stranded at least 142 hunters (and others who managed to rescue themselves). The 1957 event was apparently unprecedented in size, severity, and extent, although smaller "collision" events of this type occur nearly every season. Large-scale calving events have occurred roughly five times in 20 years (19802000), but the 1997 event involved the greatest number of people. Because they describe events that caught the whale hunters by surprise, the two case studies are relevant to questions of global environmental change. As changes affect sea ice, will the knowledge of hunters and others who use that environment be able to keep pace? For instance, with deteriorating spring ice conditions, one possible adaptation would be for the Barrow whale hunters to focus more heavily on the autumn whale hunt. Or will the environment pose greater challenges in the form of more frequent accidents, particularly if conditions are outside previous experience and expectation? Examining past events illustrates how communities respond to surprises. In terms of human dimensions research, this is a particularly compelling area for understanding the potential effects of global change both on traditional activities and on the cultural aspects of environmental knowledge.

These case studies are based on extensive narratives prepared from interviews with whale hunters and information from other sources, such as weather records, remote sensing data, and archival material. For this paper, three points are relevant, as described in more detail below. First, the breakup of shorefast ice is the result of many factors that defy reduction to simple variables or warning signs. Whale hunters, in their uncertainty about these factors, tend to err on the side of caution. Second, the presence of technology may cause some hunters to become overconfident and therefore less cautious. Whale hunters lacked even radios and weather forecasts in 1957, but were equipped with two-way radios, GPS units, snow machines, and search-and-rescue capabilities in 1997. Third, the 


\section{Flat ice zone between shore and ridges Ignignaq}

\section{Salt-free Multiyear Sea Ice Piqaluyak}

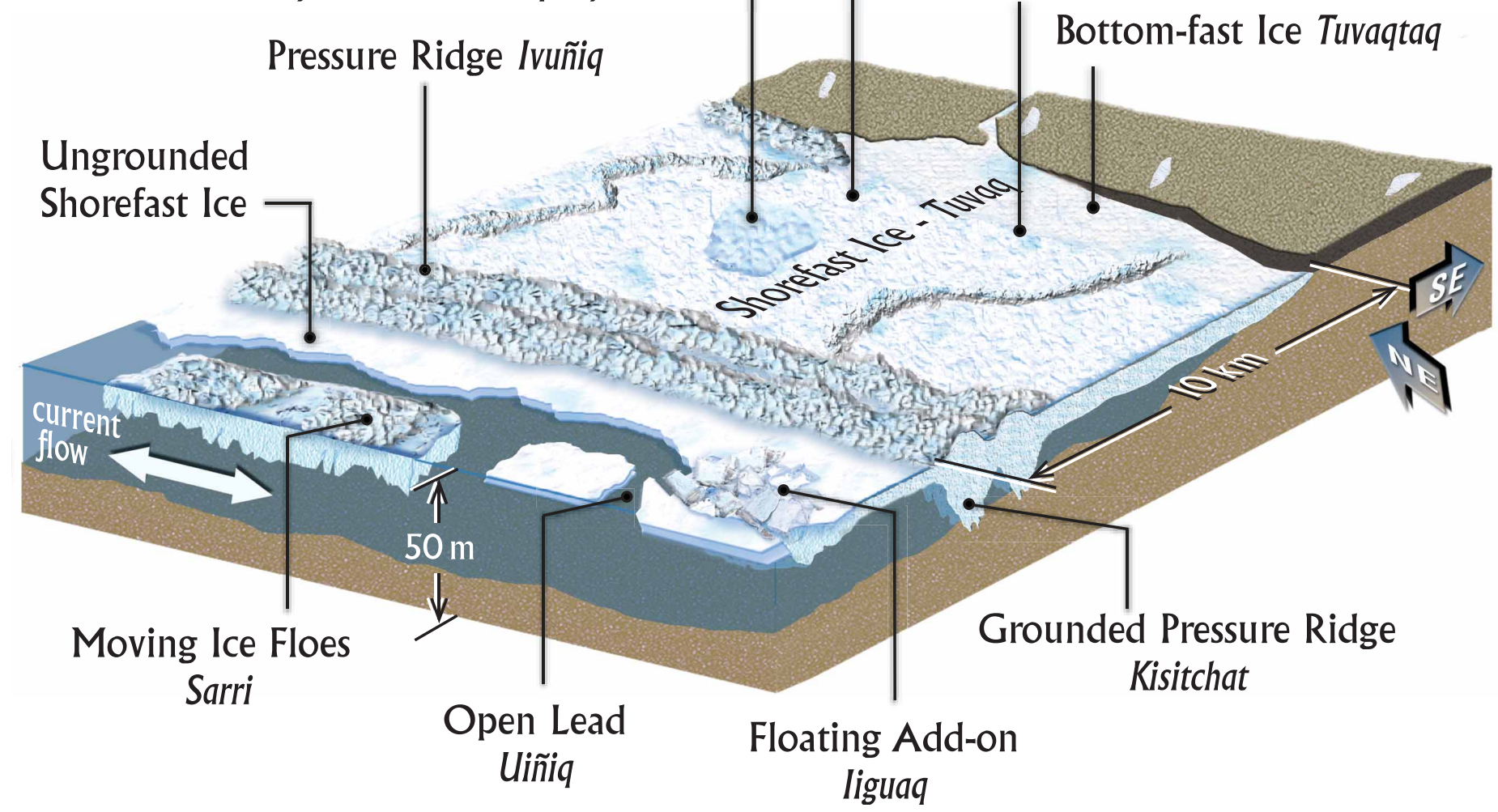

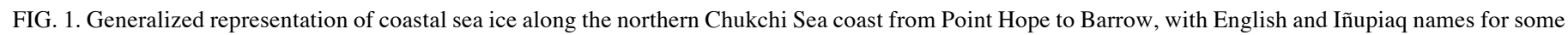
of the ice structures (illustration by Deb Coccia).

lasting impact of the experiences on those involved appears to depend in part on the degree to which the whale hunters felt they were at risk or, conversely, to which they or the search-and-rescue teams were able to control the situation.

The main objectives of this paper are 1) to describe the Iñupiat reliance on sea ice and the risk associated with that reliance; 2) to describe the shorefast ice platform, the inherent unpredictability of shorefast ice dynamics, and recent changes in sea-ice character/stability; and 3) to examine natural and societal factors that influence decision making about risk.

\section{THE IÑUPIAT AND SEA ICE}

Iñupiat hunters travel, camp, and hunt on sea ice. Shorefast ice is unique, being neither marine nor terrestrial but combining elements of both. Shorefast ice is used from late fall, when it attains enough strength to support a person, through the spring, when it melts and breaks up. For millennia, humans in the Arctic have depended on sea ice as a substrate for human activity as well as a habitat for marine mammals and other prey species. During that time, hunting communities have accumulated considerable knowledge about the ice, its characteristics, and its dangers (Nelson, 1966, 1969, 1982; Okakok, 1981). This expertise was the foundation for the Barrow Symposium on Sea Ice, during which the Iñupiat participants described some aspects of their understanding of and relationship with sea ice.

In the waters off Barrow, hunters recognize three basic sea-ice zones, each with its own ice types and dynamics (Figs. 1, 2). First is the innermost zone of shorefast ice (tuvaq), the extent of which varies within and between years. It consists of first-year ice mixed with varying amounts of multi-year ice. Second is a band that includes the open lead (uiñiq), sometimes referred to as the flaw lead, and the ice fragments moving loosely within this alongshore flaw lead. This band, where seal and whale hunting take place, is a highly dynamic region and is used with caution. Third is the outer realm of ice pack (sarri), which in the northern Chukchi Sea of Alaska consists of variable, high-velocity currents and constantly shifting sea ice that hunters regard as particularly dangerous. Iñupiat of the northern Chukchi Sea coast of Alaska rarely hunt in this outer section of the flaw zone. Hunters from Little Diomede Island in the Bering Strait, by contrast, make little use of shorefast ice, but have mastered remarkable skills for hunting and traveling on moving sea ice (John Burns, pers. comm. 1997).

The shorefast ice system at Barrow is complex: at any one instant, it reflects combined effects of wind, currents, 


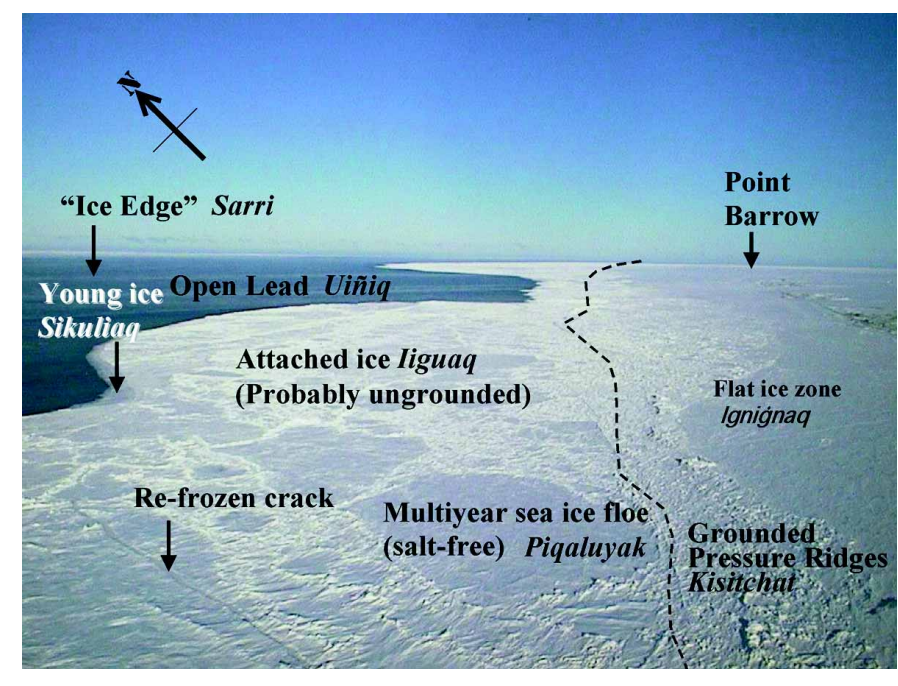

FIG. 2. Oblique aerial view of shorefast ice, tuvaq, looking NE from Barrow toward Point Barrow on 6 March 2000. English and Iñupiaq names are given for the ice types shown. Dashed line shows approximate limit of grounded ice.

interaction with the offshore ice pack and the seafloor, and the qualities of the ice itself. The presence of multi-year ice, which is thicker and stronger than first-year ice and often grounds in shallow water, affects the behavior of the shorefast ice that is undergoing stress (as explored in the first case study below). The patterns of winds and currents during fall and winter are critical to the formation of the ice, the grounded pressure ridges, and the multi-year ice pans that help give it stability. Understanding the susceptibility of the ice to subsequent winds and currents requires knowing the conditions under which it formed. For example, hunters keep track of the direction of ice movement during accretion of the shorefast ice and the direction and magnitude of the winds that created the grounded pressure ridges.

One of the Iñupiat hunters' main concerns is safety. The hunters often discuss ice conditions and dangers among themselves, in terms of specific conditions during the whaling season and generally throughout the year. The placement of whaling camps and other significant activities is based on careful appraisal of the hazards of the ice and the desirability of locations for hunting (Nelson, 1982). The whale hunters, whose camps include extensive and expensive equipment, avoid risk to life and property by retreating behind grounded pressure ridges when moving pack ice closes the lead or conditions pose other threats to the edge of the shorefast ice.

The traditional emphasis on safety and caution is illustrated with numerous past events in which the ice broke off, carrying hunters and their camps out to sea. The oral history record includes age-old stories about hunters drifting out, or getting into life-threatening situations, on moving sea ice, and recent hunters also talk about similar experiences of their own (North Slope Borough, 1980; Okakok, 1981). The prevalence of these stories indicates that ice break-offs and risky ice conditions have been regular occurrences in the past. Despite the accumulation of considerable knowledge by Iñupiat hunters, the Arctic sea-ice environment can catch people by surprise (Fig. 3a, b). The retelling of these stories and personal observations among Iñupiat hunters is an important way in which they try to avoid such accidents. Critical knowledge is passed on to inexperienced young hunters, emphasizing the importance of paying attention to the ice and to safety (Nelson, 1982).

One recent ice break-off event is described in the second case study below. The several interpretations of these events range from changing ice conditions to the loss of knowledge about sea ice to a reliance on - and faith in communication and emergency rescue technology, such as two-way radios, global positioning system units (GPS), and rescue helicopters. The impacts of such technology on risk assessment by the whale hunters is hard to determine, but some community members express concern that modern gadgetry is replacing detailed knowledge of sea ice. An analogy for non-Natives is the criticism of modern mountain climbers that they "carry their skills in their backpacks" (high-tech ice tools, GPS, rock-bolts, high-tech clothing, etc.), but lack the thorough mountaineering knowledge of earlier generations of climbers.

\section{SEA-ICE DYNAMICS}

At Barrow, freeze-up typically occurs in November, but the formation of stable shorefast ice may be delayed. Stability is achieved after one or more significant pack ice "shoves" deform and ground the ice. Grounding can take place as late as January - or not at all. Thin, ungrounded, maturing ice in the nearshore area is vulnerable. A strong offshore wind can tear away young ice all the way to the beach, leaving open water even when winter temperatures are low. In "cold years," the ice tends to stabilize by November, but recently ice has been (more) unstable, with episodes of shorefast ice breaking off at the beach as late as January or February, or almost to the beach, as in March 2002. Late-season break-offs significantly affect the ice conditions the whale hunters will face in the spring. Since formation of the shorefast platform has to re-start, the ice will take longer to stabilize and mature.

Once grounded and stabilized, the shorefast ice cover remains in place until the start of breakup in late spring and early summer. In winter, interaction between the offshore ice pack, (sarri, which responds to wind and ocean forcing) and the shorefast ice can result in rapid deformation of a few metres within hours (Weeks et al., 1977) or thickening and strengthening of ridges over longer periods (Shapiro, 1976; Reimnitz et al., 1978). This interaction typically does not lead to disintegration or break-off of shorefast ice, but rather tends to increase its stability by increasing the loading of grounded pressure ridges along the outer margins, where much of the deformation occurs (Fig. 1; Shapiro, 1976; Reimnitz et al., 1978). Further elements that add to the stability of the shorefast ice are grounded multi-year ice floes and smaller ridges that were 


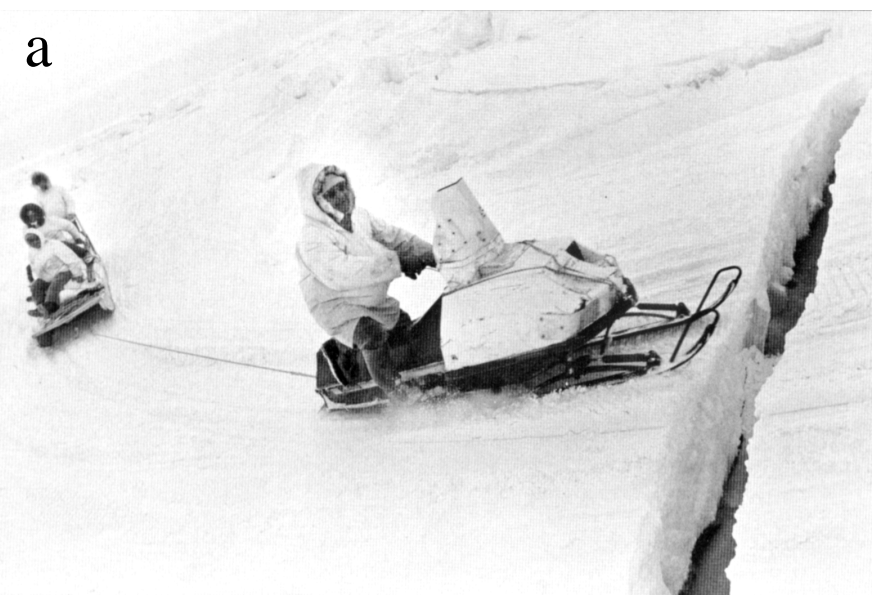

FIG. 3. a) Whale-hunting crew retreating to shore across a widening crack in 1988 (Photo: Bill Hess, Running Dog Publications).

FIG. 3. b) An $i v u$ or ice-ridging event that formed an unusual (12-13 m) ridge in the shorefast ice near Barrow, after it was hit by pack ice (May 2003). Such events often happen quickly (10-20 minutes) and can threaten hunters, camps, and equipment (Photo: J.C. George).

blown close to shore prior to or during freeze-up (Fig. 1; Shapiro, 1976).

The dynamics and breakup or decay of the complex shorefast ice cover, comprising different zones and units, is difficult to predict. Other than simple ice-melt models that predict the overall thinning through melting (Bilello, 1980), we are not aware of any work that addresses this problem for the type of ice encountered along the northern coast of Alaska. Some progress has been made in assessing the role of wave dynamics in the breakup of flat fast-ice sheets of homogeneous thickness and properties that border on deep, open water (Squire, 1993), but shorefast ice in most Alaskan locations does not conform to such a simple geometry. Russian researchers have addressed this problem for the simpler configuration of sea ice in the Laptev Sea (Spichkin, 1961). Ice-sheet flexural oscillations at periods of tens of seconds to several minutes have been tentatively identified as precursors to ice breakup, and recent modeling suggests that there may be links between such oscillations and the impact of shelf gravity waves (Marchenko et al., 2002). Similar oscillations have been recorded in the shorefast ice at Barrow, where "waves" with an amplitude of $2-8 \mathrm{~cm}$ and a period of five to ten minutes occur (Shapiro and Metzner, 1989:18; North Slope Borough, 1999-2002; Norton, 2002).

Satellite remote sensing can help provide data on the breakup of shorefast ice (e.g., Barry et al., 1979). Data of sufficient ground resolution to allow conclusions about actual processes and smaller-scale events have only recently become available, however (Hirose and Vachon, 1998). Satellite-borne synthetic aperture radar (SAR) can discriminate between shorefast ice, water in an open lead, and drifting ice (Fig. 4). With an effective resolution of about 50 to $100 \mathrm{~m}, \mathrm{SAR}$ is particularly useful in studying the evolution of coastal ice. Orbit repeat times, which

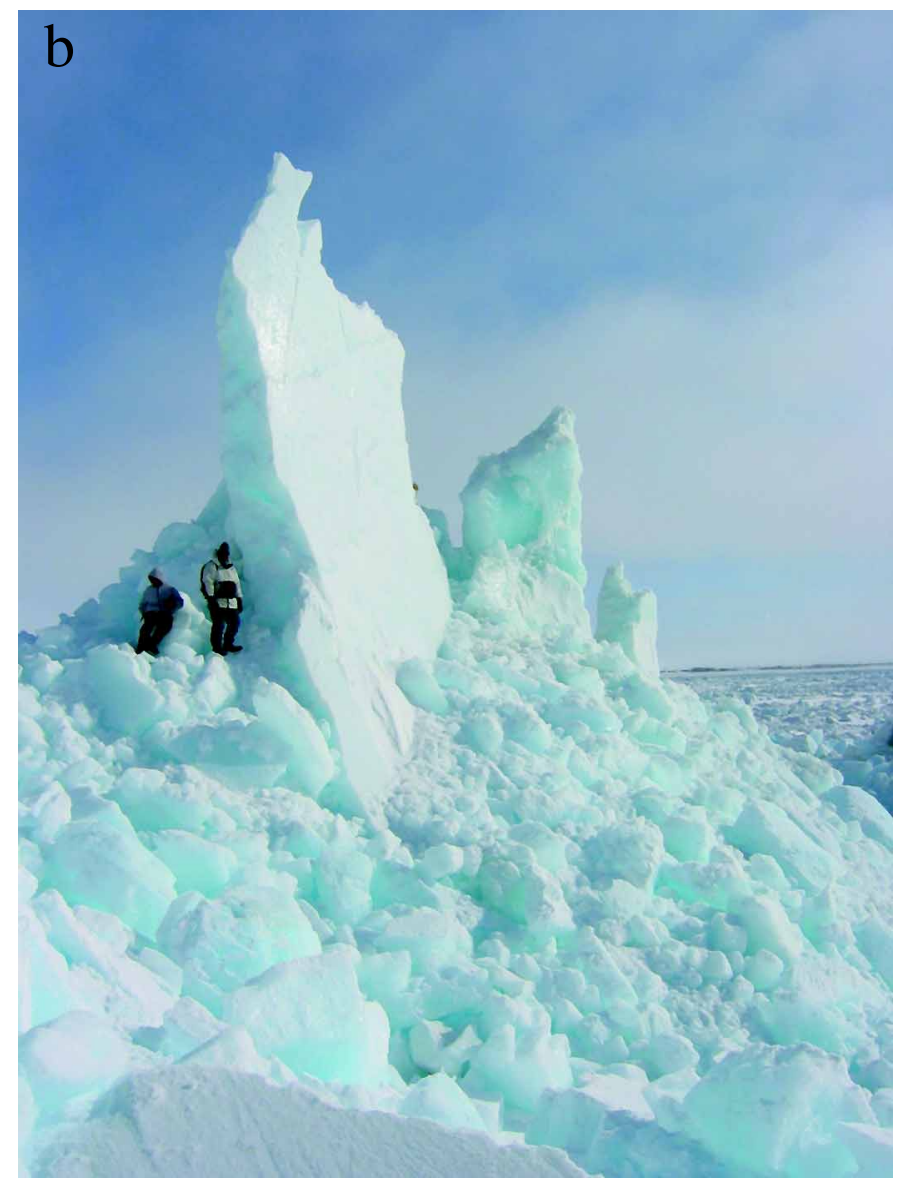

range from a few days to three weeks, make near-real-time observations of fast-ice deformation problematic, whereas successive SAR images are useful in tracking movement of floes in the Chukchi flaw zone (Norton and Gaylord, 2004, this volume). SAR images, however, do provide some insight into the morphology, zonation, and component floes of the shorefast ice zone. Considering the strengths and weaknesses of satellite remote sensing, data sets that would be useful for the development of conceptual and numerical models of breakup and decay of shorefast sea ice would probably entail a combination of several data sources. These include remote sensing, ground-based observations at different locations on the ice sheet, a marine radar providing near-continuous, near-real-time data on ice evolution and deformation at a scale of several kilometres (Shapiro, 1976), and the relevant meteorological and atmospheric forcing data sets.

The increased frequency of winter and early spring break-off events and shortened sea-ice seasons (Huntington, 2000) suggests that the coastal sea-ice system has been responding to some of the recent changes observed in the Arctic atmosphere and ocean (Serreze et al., 2000) and that the shorefast ice regime has become more dynamic. Significant gaps remain in our understanding of ice breakup and decay, as was shown by the inability to predict the ice break-off events in the winter of 2001-02.

On the morning of 11 December 2001, significant parts of the shorefast ice cover broke off and drifted away 


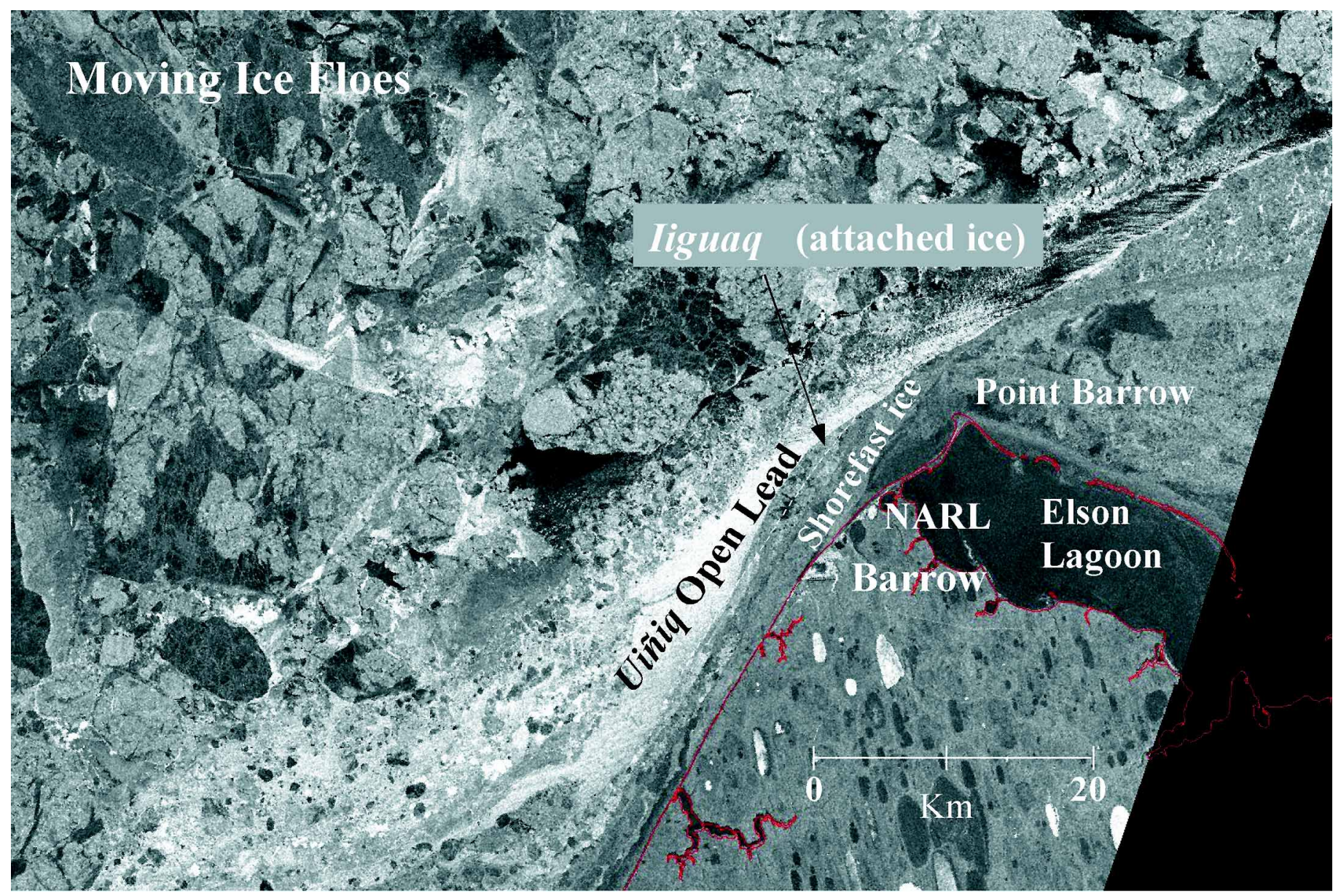

FIG. 4. A synthetic aperture radar satellite scene (1 May 2001) centered on Barrow, Alaska, showing shorefast ice and the "lead system" with drifting fragmented ice (sometimes referred to as the "flaw zone") farther offshore. Note the iiguaq (multi-year ice that attached to the shorefast ice). The dotted white line shows where the iiguaq attached in late March 2001. The iiguaq appears lighter in this image than the nearby shorefast ice, which consisted mostly of first-year ice.

between the town of Barrow and Utqiagvik Inupiat Corporation-NARL (see Fig. 4 for location). Later in the same winter, on 17 March 2002, another break-off event caught 18 seal hunters and a whaling crew off-guard, and all had to be rescued by helicopter. Following these pre-whaling season events, the shorefast ice grew back. Although the "regrown" ice did not achieve the thickness of the undisturbed ice that had started forming in November 2001 (1.6 $\mathrm{m}$ off NARL), the lack of a significant snow cover did allow for substantial ice growth (over $1 \mathrm{~m}$ ). The final event of the 2002 season occurred when a major portion of the shorefast ice broke up in May and took more than 50 whale hunters out to sea. They, too, had to be rescued by boats and helicopter.

Although more research is needed to explain the environmental factors responsible for these events, it is likely that 1) the lack of grounded multi-year ice floes and 2) the reduced pressure ridges (both along the offshore ice edge and over shoals within the shorefast ice zone; Shapiro, 1976) tend to increase the likelihood of early break-off and breakup events. Lack of multi-year ice as a stabilizing component of the shorefast cover can be directly traced to the large-scale reductions in summer minimum pack-ice extent in the Chukchi and Beaufort seas (Serreze et al., 2000; Harry Brower, Jr. pers. comm. 2000).

Alternatively, the lack of multi-year floes in the shorefast ice can be ascribed to the weather systems occurring just before freeze-up. Sometimes many multi-year floes are blown in, as happened in fall 2001, and at other times the ocean "freezes in place," with few or no multi-year floes present. Even in the latter case, multi-year floes can be incorporated into the shorefast edge if they "migrate" in from the west over the winter and are accreted to the existing ice by strong westerly winds and currents. The reduced ridging observed in 2000-01 and 2001-02 was due to a number of factors, including the local meteorological regime. Moreover, it is not clear whether reduced ice thickness ( 1.5 to $1.6 \mathrm{~m}$ in recent years, as compared to about $1.8 \mathrm{~m}$ in the 1970s; Weeks and Gow, 1978) enhances or diminishes the degree of ridging. Early winter break-off events nevertheless tend to increase the likelihood of early spring breakup. Since less time is available for the formation of thick ice, for multi-year floes to freeze in, and for interaction between moving ice floes and shorefast ice to produce the grounded pressure ridges that buttress the shorefast ice, early winter break-offs leave the shorefast ice generally thinner and weaker. 


\section{7: CATASTROPHIC BREAKUP}

In early May 1957, Barrow's whaling crews were at the ice edge looking for whales, in clear, calm weather. The wind began to increase from the southwest, building rapidly to $40 \mathrm{~km} / \mathrm{h}$ with stronger gusts. The water level rose from the storm surge, and soon floes at the edge of the ice pack (sarri) were seen, moving rapidly towards the edge of the shorefast ice. The whale hunters rushed to pack their gear and retreat, but the moving ice came too fast. When moving ice hits the shorefast ice, the latter often buckles at the edge to produce a new pressure ridge, but there is little visible impact away from the edge. However, this is not always the case: the effect of an impact depends on the thickness of the moving floes, the thickness and strength of the shorefast ice, and the velocity with which the moving ice hits (Fig. 3b).

In 1957, the shorefast ice simply shattered all the way to shore (but not up the beach) when the pack ice smashed into it. The whale hunters were shocked. Their retreat turned into a scramble for the safety of shore, with sled dogs cut loose and equipment abandoned. Remarkably, no lives were lost. Nonetheless, it took years for many of the crews to recover and acquire new equipment. By any reckoning, it was an extraordinary event (Huntington et al., 2001, 2002; Norton, 2002; K. Toovak, Sr., pers. comm. 2003; Brewster, 2004).

The sudden onset of a strong storm from the southwest appears in Barrow's weather records several times in the 20th century. But we know of no other accounts that connect such weather to the nearly complete destruction of shorefast ice. Indeed, there is no other record of shorefast ice shattering in this particular manner, which helps explain why the whale hunters were caught off-guard. Review of weather records and reconstruction of the storm indicate that a deep low-pressure system was moving north over eastern Siberia (Norton, 2002). As a result, 90-knot $(\sim 165 \mathrm{~km} / \mathrm{h})$ SW winds just south of the Bering Strait pushed water up the coast in the form of a surge, which lifted the shorefast ice and increased its susceptibility to breaking up. Sea-level surges accompany west and southwesterly storms, but since no other storm produced this effect on the shorefast ice, the ice type itself may have been the decisive factor.

In that year, there may have been an unusually high proportion of salt-free, multi-year ice, known in Iñupiaq as piqaluyak, incorporated into the shorefast ice. Piqaluyak refers to a specific type of multi-year ice. Floes can be as much as $10 \mathrm{~m}$ thick, and are derived from old, compacted pressure ridges that have survived two or more seasons of freezing and thawing (riverine or glacial contributions to piqaluyak are thought to be rare). During successive summers, some of the surface ice melts, percolates through the underlying ice, and flushes out the denser, entrapped brine, thereby "freshening" the ice. Piqaluyak floes have many properties not found in regular first-year ice floes. Because of the leaching of the brine and its replacement by relatively fresh water, piqaluyak floes yield excellent potable water that is used by the whaling crews. Piqaluyak floes are harder and more brittle. Within the shorefast ice setting, they can take considerable force, but when they eventually break, they can shatter like glass, occasionally in an "explosive" manner. This brittleness contrasts to the less violent flexing, fracturing, and ridging of the more saline first-year floes.

That the whale hunters were caught off guard is perhaps the most significant part of the story. There were few indications of an imminent storm, and in 1957, there was no radio station to broadcast weather forecasts that would warn those on the ice about changing conditions. There was little warning of disaster from any source. Once it became apparent that ice was moving in from farther offshore, the crews attempted to retreat to safe ice behind the grounded pressure ridges, a strategy that usually offers sufficient protection. In this case, the pressure ridges did not hold against the force of the incoming ice, and they broke up along with the piqaluyak floes that had been incorporated into the shorefast ice. This event emphasized to whale hunters what their elders had taught them about the insecurity of flat, wide pans of multi-year, salt-free piqaluyak. Since the 1957 event, younger whale hunters have been told to avoid camping or seeking refuge on piqaluyak.

For the whale hunters involved, the event was powerful and memorable. Many regarded themselves lucky to have made it to shore, despite losing all the gear they had taken on the ice. The whale hunters are aware that the ice is not always predictable. Their elders trained them to watch the wind and current at all times, and to retreat quickly under certain conditions. Despite their best efforts, they were caught off guard and nearly became victims of a disaster. Subsequent generations of whale hunters have been taught the lessons learned in the first week of May 1957. Weather forecasts now provide advance notice of incoming storms a key new development. Forecasts allow whale hunters time to assess the conditions and risks and decide whether to remain or retreat. Nonetheless, as the next case study shows, there are other ways of being caught by surprise.

\section{7: WHALE HUNTERS STRANDED BY AN ICE-CALVING EVENT}

The shorefast ice is not static. Portions of the ice can break off, an event known as "calving," which is one of the major hazards of the shorefast ice (Fig. 3a). The Iñupiat term uisauniq has been translated as "a calving event involving people," [uisau 'to be stranded on an ice floe in the ocean' + niq 'to report or confirm that the subject is uisau-ing'] (Maclean, 1980). The existence of this term gives some indication of the significance of such an occurrence. Between 1980 and 2000, five large-scale calving events took place near Barrow, three of which carried people out on the newly mobile ice. The calving event of 1997 was the most significant of the five, carrying off 12 
TABLE 1. Western and Iñupiat theories regarding the causes of uisauniq ("major ice calving events involving people").

\begin{tabular}{|c|c|}
\hline $\begin{array}{l}\text { Western Science: } \\
\text { Cause }\end{array}$ & Comments \\
\hline $\begin{array}{l}\text { Stress from offshore winds and interactions between pack } \\
\text { ice and fast ice (Reimnitz et al., 1978) }\end{array}$ & $\begin{array}{l}\text { Stresses imparted on the shorefast ice by offshore winds and the ice-pack converging on the } \\
\text { coastal zone may break shorefast ice free. }\end{array}$ \\
\hline $\begin{array}{l}\text { Wind- or current-induced "oscillations" (Shapiro, 1976; } \\
\text { Shapiro and Metzner, 1989) }\end{array}$ & $\begin{array}{l}\text { L. Shapiro noted that major shorefast ice movements were preceded by "oscillations" in the ice } \\
\text { with a } 10 \text {-minute period. }\end{array}$ \\
\hline $\begin{array}{l}\text { Storm surge, spring neap-tide, regional oceanographic } \\
\text { circulation (Kozo et al., 1987; R. Page, pers. comm. 2002) }\end{array}$ & $\begin{array}{l}\text { Storm surges through the Bering Strait may cause sudden increases in sea level and cause } \\
\text { shorefast ice to fail. }\end{array}$ \\
\hline $\begin{array}{l}\text { Iñupiat Science: } \\
\text { Cause }\end{array}$ & Comments \\
\hline Тииq effect (pack ice collision, often distant; 1997) & Pack ice acts like a chisel or "tииq" on the shorefast ice. \\
\hline Sudden tide or sea level change & Hunters describe sudden changes in sea level that can affect the stability of shorefast ice. \\
\hline Sea-current pressure & Pressure from sea currents pushing on the shorefast ice cause it to fail. \\
\hline "Katak Theory" & $\begin{array}{l}\text { A sudden "drop" ( } k a t a k \text { means 'to fall') in sea level can crack the shorefast ice near grounded } \\
\text { ridges, causing it to fail at that point (Norton, 2002). }\end{array}$ \\
\hline Offshore (shore-normal) under-ice current & $\begin{array}{l}\text { Hunters have observed occasional under-ice, shore-normal currents (perpendicular to the ice } \\
\text { edge) that cause the shorefast ice to break off. }\end{array}$ \\
\hline Ocean waves; and 1964 earthquake effect (?) & $\begin{array}{l}\text { Hunters have described large waves (tsunami) occurring on calm days, possibly from distant } \\
\text { earthquakes (Okakok, 1981). K. Toovak noted that the shorefast ice broke free at Barrow after } \\
\text { the Good Friday earthquake that struck Alaska on } 27 \text { March } 1964 \text {. }\end{array}$ \\
\hline Moon tides & Iñupiat hunters recognize the effect of moon phase on tides and instability in shorefast ice. \\
\hline Weak areas at iiguaq & $\begin{array}{l}\text { Shorefast ice is weakest at the junction of two shorefast ice masses, where they "attach" (iiguaq } \\
\text { means " attachment"). }\end{array}$ \\
\hline
\end{tabular}

whaling camps with about 142 people, who were eventually rescued by helicopter. Several more people who were near the fracture zone returned to land by boat, so the number of people affected is somewhat greater than 142 .

As noted above, shorefast ice is typically held in place by grounded pressure ridges and, to a lesser extent, by grounded multi-year ice floes, which anchor the floating ice to the seabed and prevent winds or currents from moving it. The pressure ridges are formed when winds and currents drive pack ice into the shorefast ice, and thus both the number and the size of the pressure ridges depend largely on the character of the winds and currents during the ice season in question. The breakup of these ridges and the shorefast ice appears to be a complex interaction of several forces in any number of combinations. Scientists and the Iñupiat agree that these forces include wind vectors, currents, storm surges, pieces of moving ice floes acting like a chisel (tuuq in Iñupiaq) on the shorefast ice, a sudden drop in sea level, possible tsunamis, tides enhanced by different phases of the moon, ice-surface and bottom melt, and the weak points in shorefast ice where new sections of ice were added. These attached sections of ice are called iiguaq in Iñupiaq. The point where an iiguaq attaches is often weak (Table 1).

There is no simple set of indicators that can be monitored to evaluate the risk of calving. Instead, the whale hunters pay attention to a wide range of parameters and typically exercise caution by retreating often, despite the relative infrequency of calving or break-off events. Whale hunters' behavior attests to the considerable instability of the sea-ice environment.

In 1997, much of the shorefast ice had broken off in March, so that in May, during whaling, the ice was relatively young and flat, with few grounded pressure ridges to anchor it in place. Despite strong east (offshore) winds in early May, the ice did not break off. When the ice did begin to move on 17 May, however, the wind was relatively light.

The current, which was flowing northward or "downlead," had been strong but not alarmingly so; it then began to strengthen noticeably, to the point that pressure-ridge blocks were "tumbling" out from under the shorefast ice and into the lead. With the strengthening current (and the rise in sea level), tide cracks flooded. The Iñupiat recognize this as an indicator that the ice may be unstable. However, flooding had been reported several times earlier in May with no bad effects, so the hunters chose to stay out on the ice. Weak spots of thin ice or weakly cemented pressure ridges visible in the trail system also became weaker. Finally, over VHF radio, a crew reported an active crack to the southwest. Within hours, much of the shorefast ice was in motion toward the northeast. It did not move as a single mass, but fractured into many pieces. The ice broke where the March iiguaq, consisting of younger and thinner ice, had been attached. 
Most whaling crews had retreated several times by the second week of whaling-one crew at least 11 times (Edward Itta, pers. comm. 1997). Because each retreat means two moves, the Itta crew moved 22 times. When a camp is pulled back, the crew usually sets up camp (again) on the shore side of the first grounded ridge, which is quite stable, illustrating the caution noted above. Several factors in the conditions and sequence of events on 17 May caused the majority of whalers not to retreat in time. A few, however, did retreat just in time. Harry Brower, Jr. was chasing a whale, but instructed his crew to leave the ice after they reported a "jolt" coming from the shorefast ice. They were able to get all but one crewmember and four of seven snow machines across the widening crack (Harry Brower, Jr., pers. comm. 2002). In retrospect, whale hunters reported noticing indications of danger, but after assessing the risks, many decided to remain on the ice.

What persuaded the crews to remain on the ice? The fact that a whale was being towed to a butchering site certainly influenced their decision. At least five boats were involved in towing the whale, and their respective crews wanted to stay on the ice to support them in the hauling, butchering, and transport of meat. Furthermore, this was the first whale for a young captain - an important event to the community. Thus, the "benefits" of retrieving the whale, and possibly harvesting additional whales, outweighed the potential risks (only a few whales had been landed prior to this).

The divided crews - some towing the whale and some on the ice-had less opportunity to reach the consensus normally needed to evacuate the ice. The decision to evacuate is sometimes the captain's decision alone (e.g., an emergency situation), but more commonly it is a "group decision" based on consultation with other crews in the immediate area. Often the same crews camp together each season and confer with each other. Also, many crews rely upon consultation with their senior whale hunter, who may be too elderly to be on the ice, but who gives advice from onshore over the radio. Weighing and taking calculated risks, based upon an assessment of conditions, is an essential part of Iñupiat whale hunting.

It was fortunate that no lives were lost with the stranding of 142 persons on newly drifting ice in the Arctic Ocean. Thick fog and snow flurries almost immediately after the break-off reduced visibility to $100 \mathrm{~m}$ or less. In each group where the hunters gathered, at least one person had a GPS unit, so that whale hunters could direct rescue helicopters to their precise location by two-way radio. A few individuals without radios had to set a fire to identify their position for the helicopter pilot. A few crews launched their boats and made it back to the shorefast ice by following directions given by helicopter pilots, who guided them through the ice-filled leads.

Without helicopter rescue, crews would have had to be self-reliant (as in the "old days") through a combination of paddling and portaging boats through water and over the ice to reach land. On the other hand, crews setting out for shore independently could easily have drifted beyond any shore-based assistance. Had their progress back toward land been impeded by steep pressure ridges, crews stranded on moving ice might have faced loss of life from exposure, lack of food, or drowning.

\section{DISCUSSION}

Neither the 1957 nor the 1997 event can be fully explained scientifically in terms of what exactly triggered them. In 1957, the whale hunters identified the presence of extensive salt-free multi-year ice (piqaluyak) as a factor in the shorefast ice shattering. The characteristics of sea ice as understood by sea-ice physicists and Iñupiat hunters, however, do not help explain what happened, and would suggest the opposite result: that the presence of multi-year ice should strengthen rather than weaken the shorefast ice (Richter-Menge, 1992; Eicken, 2003). Several factors about which little is known may have played a critical role. These include the exact composition of the ice, the possibility of failure through mechanisms such as differential vertical movement, and the effect of differences in thickness between the moving ice and the shorefast ice. Movement of thicker ice floes impinging on thinner shorefast ice appears to cause more immediate ice-edge damage and deformation than the opposite situation, when thinner pack ice hits heavy shorefast ice. On the other hand, some captains have commented that young ice can place great pressure on shorefast ice. This is in part due to the momentum associated with such a back-and-ram event, which can play an important role in the evolution of ice shoves (Mahoney et al., in press). At the same time, younger ice, even up to thicknesses of around $1 \mathrm{~m}$, has been observed to raft and ridge, whereas multi-year ice typically does not fail and buckle in the open pack. In a coastal setting, however, substantial stress can build up through integration of wind and water stress over larger distances, and this clearly plays an important role in the explanation of such dramatic failure events. One can argue that the weakening of the pack ice caused by reduction in multi-year ice and overall thinning of perennial ice in the Beaufort Sea and Arctic Ocean (Tucker et al., 2001), in combination with the lack of onshore multi-year ice, is sufficient to have made catastrophic winter breakup events much less likely. Lacking the relevant physical data, we can only speculate at this stage on the conditions that result in catastrophic failure of desalinated multi-year ice. Although the traditional knowledge of coastal inhabitants suggests using first-year ice as a platform for drifting ice camps, researchers prefer thick multi-year ice.

The 1997 event appears more straightforward, at least to the extent that the March break-off weakened the shorefast ice-a pattern that was repeated in 2002. Nonetheless, it is not clear why the ice broke when it did, or how the whale hunters could have predicted the particular moment, in view of the $\sim 11$ times that the Itta crew had retreated from ice that remained solid. Some captains did 
warn the crews to leave the ice as the current speed increased and the tide cracks flooded. Roy Ahmaogak and his son left camp shortly before the calving event and were among the last to cross the ice before stranded crews drifted northward.

The long-term effects of the near-disaster in 1997 are less clear than those of the 1957 event. The 1957 event provided lessons about avoiding camping on brittle piqaluyak and an appreciation for the availability of weather forecasts. The effect of the successful rescue in 1997 may have heightened confidence in search-and-rescue capabilities and raised whale hunters' threshold of willingness to retreat to safety. It is premature to draw such a conclusion, but some of the Iñupiat at the Barrow Symposium on Sea Ice expressed concern that people now take more risks on the ice because of the safety net provided by modern technology.

This technological change, which confers many advantages and improvements in safety coupled with the additional risks noted by the hunters, parallels a more general societal change in which the wisdom of the elders is passed on less thoroughly than in the past (e.g., Fehr and Hurst, 1996). Ice knowledge, however, unlike some skills like dog mushing, is still rich, still useful, and still transferred to younger hunters.

Alternatively, in the case of sea-ice knowledge, it could be that the accumulated information about ice held by the elders is less applicable today because of environmental change (Norton, 2002). Today's hunters may find the old lessons about currents, wind, and ice conditions less useful than in the past, because the ice and environmental conditions today differ from those studied by their elders. That is, generations ago the ice may have been more stable and consistent from year to year (owing to cooler, less stormy conditions) and therefore more predictable. Instead, today's hunters have added their own experience to the old and created a new information base that better reflects modern ice conditions. Acquiring new technology and the ability to adapt hunting procedures is well documented in the literature (Berkes, 2002). An important topic for further research is the relative impacts of such societal and environmental changes on the relationship between Arctic residents and their environment. In the case of sea ice, one such line of inquiry is a more detailed study of the impacts of changing technology on risk perception and behavior.

The present study focuses on a sea-ice environment that is characterized by the interaction between a comparatively narrow shorefast ice zone and the offshore drifting ice pack. Here, the sea-ice regime is comparable to that in other coastal communities in the Beaufort and Chukchi seas (Mahoney et al., in press) and may also apply to St. Lawrence Island (Krupnik, 2002), as well as to communities in the Hudson Bay and Baffin Bay area. In the former region, it is the catastrophic breakup of the ice cover that is of particular interest, although with a less dynamic offshore sea-ice environment, melt and disintegration processes may play a more important role (McDonald et al.,
1997; Fox, 2002). The latter also holds for the Siberian Arctic, where the broad shorefast-ice extent in the Kara, Laptev, and East Siberian seas and the differences in circulation regimes diminish the importance of offshore ice dynamics from the perspective of coastal residents (Reimnitz et al., 1994). However, common to all these coastal areas is the central aspect of anticipating ice breakup, whether as a catastrophic midwinter event or at the end of the ice season.

More generally, scientific understanding of the nearshore zone, including shorefast ice, is likely to remain imperfect because of the inherent complexity of that environment (Reimnitz et al., 1978). Further collaborative research between whale hunters and scientists should look more systematically (and prospectively) at the ice conditions and dynamics, and also at the ways in which whale hunters acquire and use information to assess the ice. The incorporation of remote-sensing information and regional weather forecasting, for example, may alter the interpretation of local indicators or (more likely) may instead be used to supplement or corroborate firsthand observations. The impacts of these kinds of changes on traditional understanding and the transmission of knowledge between generations is particularly important to understanding change and stability in the human-environment relationship of Arctic communities.

Whale hunting is inherently dangerous. Hunters know they must subject themselves to considerable risk, and they are willing to accept consequences that non-hunters would find unacceptable. Whale hunters are also accustomed to a variable and uncertain environment. This inherent flexibility allows them to adapt to new conditions. The rapid adoption of new technology to improve safety, whether it is faster snow machines or GPS units to aid navigation, illustrates reducing risks. Even for those who expect the unexpected, there can be serious mishaps, as the above events indicate.

Our collective understanding of shorefast ice needs to reflect the ways that people interact with the ice and the resources that the ice makes accessible. Specifically, scientists must consider people's uses of sea ice, assessments of risks and benefits, and their observation and interpretation of environmental indicators (whether directly or through modern technology) to predict future trends. The dynamic nature of the shorefast ice and its effect on Arctic communities must be considered along with the dynamic nature of the societies that use it.

\section{ACKNOWLEDGEMENTS}

We thank the National Science Foundation (NSF) for supporting the Barrow Symposium on Sea Ice through the Human Dimensions of the Arctic System (HARC) initiative, NSF grants OPP-9908682 and 0117288 to D.W. Norton. Ice mass balance observations were supported through NSF grant OPP-9910888 to H. Eicken. We appreciate the support and advice of our mentors within the Barrow 
Whaling Captains' Association. Although the captains are too numerous to mention here, we are grateful to all of them. The success of the symposium depended on the commitment and active involvement of all of its participants. Allison Graves Gaylord processed SAR imagery in Barrow overcoming a number of obstacles. Carla Willetto, the Barrow Arctic Science Consortium, and the North Slope Borough Department of Wildlife Management were instrumental in setting up and administering the symposium. We are particularly grateful to Warren Matumeak, Raymond Neakok, Arnold Brower, Sr., Jonathan “Kunuq” Aiken, Sr., Harry Brower, Jr., Kenneth Toovak, and Wesley Aiken, who participated in formal oral history interview sessions. We thank Bill Hess of Wasilla, Alaska, for the use of his photograph of whale hunters escaping the ice (Fig. 2a). We thank the European Space Agency for use of the SAR images of the sea ice.

\section{REFERENCES}

BARRY R.G., MORITZ, R.E., and ROGERS, J.C. 1979. The fast ice regimes of the Beaufort and Chukchi sea coasts, Alaska. Cold Regions Science and Technology 1(2):129-152.

BERKES, F. 2002. Epilogue: Making sense of Arctic environmental change? In: Krupnik, I., and Jolly, D., eds. The Earth is faster now: Indigenous observations of Arctic environmental change. Fairbanks, Alaska: Arctic Research Consortium of the United States. 334-349.

BILELLO, M. A. 1980. Maximum thickness and subsequent decay of lake, river and fast ice in Canada and Alaska. CRREL Report 80-6. 160 p.

BREWSTER, K.N. 2004. The whales, they give themselves: Conversations with Harry Brower, Sr. Fairbanks: University of Alaska Press.

DMITRENKO, I., GOLOVIN, P., GRIBANOV, V., and KASSENS, H. 1999. Oceanographic causes for Transarctic ice transport of river discharge. In: Kassens, H., Bauch, H., Dmitrenko, I., Eicken, H., Hubberten, H.W., Melles, M., Thiede, J., and Timokhov, L., eds. Land-ocean systems in the Siberian Arctic: Dynamics and history. Berlin: Springer-Verlag. 73-92.

EICKEN, H. 2003. From the microscopic to the macroscopic to the regional scale: Growth, microstructure and properties of sea ice. In: Thomas, D.N., and Dieckmann, G.S., eds. Sea ice: An introduction to its physics, biology, chemistry and geology. London: Blackwell Scientific Ltd. 22-81.

FEHR, A., and HURST, W. 1996. A seminar on two ways of knowing: Indigenous and scientific knowledge. Inuvik, Northwest Territories: Aurora College. 93 p.

FOX, S. 2002. These are things that are really happening: Inuit perspectives on the evidence and impacts of climate change in Nunavut. In: Krupnik, I., and Jolly, D., eds. The Earth is faster now: Indigenous observations of Arctic environmental change. Fairbanks: Arctic Research Consortium of the United States. 12-53.

HIBLER, W.D., III. 1986. Ice dynamics. In: Untersteiner, N., ed. The geophysics of sea ice. NATO ASI Series B, Physics, Vol. 146. New York: Plenum Press. 577-640.
HIROSE, T., and VACHON, P.W. 1998. Demonstration of ERS Tandem Mission SAR interferometry for mapping land fast ice evolution. Canadian Journal of Remote Sensing 24(1):89-92.

HUNTINGTON, H.P. 2000. Native observations capture impacts of sea ice changes. Witness the Arctic 8(1):1-2.

HUNTINGTON, H.P., BROWER, H., Jr., and NORTON, D.W. 2001. The Barrow Symposium on Sea Ice, 2000: Evaluation of one means of exchanging information between subsistence whalers and scientists. Arctic 54(2):201-204.

HUNTINGTON, H.P., BROWN-SCHWALENBERG, P.K., FERNANDEZ-GIMENEZ, M.E., FROST, K.J., NORTON, D.W., and ROSENBERG, D.H. 2002. Observations on the workshop as a means of improving communication between holders of traditional and scientific knowledge. Environmental Management 30:778-792.

KOVACS, A., and SODHI, D.S. 1980. Shore ice pile-up and rideup: Field observations, models, theoretical analyses. Cold Regions Science and Technology 2:210-288.

KOZO, T.L., STRINGER, W.J., and TORGERSON, L.J. 1987. Mesoscale nowcasting of sea ice movement through the Bering Strait with a description of major driving forces. Monthly Weather Review 115(1):193-207.

KRUPNIK, I. 2002. Watching ice and weather our way: Some lessons from Yupik observations of sea ice and weather on St. Lawrence Island, Alaska. In: Krupnik, I., and Jolly, D., eds. The Earth is faster now: Indigenous observations of Arctic environmental change. Fairbanks: Arctic Research Consortium of the United States. 156-197.

MACDONALD, R.W. 2000. Arctic estuaries and ice: A positivenegative estuarine couple. In: Lewis, E.L., ed. The freshwater budget of the Arctic Ocean. Dordrecht: Kluwer Academic Publishers. 383-407.

MACLEAN, E.A. 1980. Abridged Iñupiaq and English dictionary. Fairbanks: Alaska Native Language Center, University of Alaska Fairbanks and Barrow: Inupiat Language Commission, North Slope Borough.

MAHONEY, A., EICKEN, H., SHAPIRO, L.H., and GRENFELL, T.C. In press. Mechanisms and driving forces during a spring ice shove on the Alaskan Chukchi coast. Journal of Glaciology.

MARCHENKO, A., MAKSHTAS, A., and SHAPIRO, L. 2002. On the excitation of shelf edge waves due to self-induced oscillations of ice floes. In: Squire, V., and Langhorne, P., eds. Ice in the environment: Proceedings of the 16th IAHR International Symposium on Ice, 2-6 December 2002, Dunedin, New Zealand. Dunedin: University of Otago. 301-309.

McDONALD, M., ARRAGUTAINAQ, L., and NOVALINGA, Z. 1997. Voices from the Bay: Traditional ecological knowledge of Inuit and Cree in the Hudson Bay bioregion. Ottawa: Canadian Arctic Resources Committee and the Municipality of Sanikiluaq. NELSON, R.K. 1966. Alaska Eskimo exploitation of the sea ice environment. Fort Wainwright, Alaska: Arctic Aeromedical Laboratory.

- - - 1969. Hunters of the northern ice. Chicago: University of Chicago. 429 p.

- - - 1982. Harvest of the sea: Coastal subsistence in modern Wainwright. Barrow, Alaska: North Slope Borough, Coastal Management Program. 126 p. 
NORTH SLOPE BOROUGH. 1980. Qiniqtuagaksrat utuqqanaat inuuniagninisiqun: Traditional land use inventory of the midBeaufort Sea, Vol. 1. Barrow, Alaska: North Slope Borough, Iñupiat History, Language and Culture Commission.

- - - . 1999-2002. Unpublished tide data for Point Barrow, Alaska. (Seabird 39; recorded at 1 minute intervals; Spring 1999-2002.) North Slope Borough, Department of Wildlife Management, Barrow, Alaska 99723, U.S.A.

NORTON, D.W. 2002. Coastal sea ice watch: Private confessions of a convert to indigenous knowledge. In: Krupnik, I., and Jolly, D., eds. The Earth is faster now: Indigenous observations of Arctic environmental change. Fairbanks, Alaska: Arctic Research Consortium of the United States. 126-155.

NORTON, D.W., and GAYLORD, A.G. 2004. Drift velocities of ice floes in Alaska's northern Chukchi Sea flaw zone: Determinants of success by spring subsistence whalers in 2000 and 2001. Arctic 57(4):347-362.

OKAKOK, L., ed. 1981. Puiguitkaat, the 1978 Elder's Conference at Barrow, Alaska. Barrow: North Slope Borough, Iñupiat History, Language and Culture Commission. 653 p.

REIMNITZ, E., TOIMIL, L., and BARNES, P. 1978. Arctic continental shelf morphology related to sea-ice zonation, Beaufort Sea, Alaska. Marine Geology 28:179-210.

REIMNITZ, E., DETHLEFF, D., and NÜRNBERG, D. 1994. Contrasts in Arctic shelf sea-ice regimes and some implications: Beaufort Sea and Laptev Sea. Marine Geology 119:215-225.

RICHTER-MENGE, J.A. 1992. Compressive strength of frazil sea ice. In: Proceedings of the International Association of Hydraulic Engineering and Research Symposium on Ice, 15-19 June 1992, Banff, Alberta. Vol. 2:1065-1074.

RICHTER-MENGE, J.A., McNUTT, S.L., OVERLAND, J.E., and KWOK, R. 2002. Relating Arctic pack ice stress and deformation under winter conditions. Journal of Geophysical Research 107(C10) 8040, doi: 10.1029/2000Jc000477.
SERREZE, M.C., WALSH, J.E., CHAPIN, F.S., III, OSTERKAMP T., DYURGEROV, M., ROMANOVSKY, V., OECHEL, W.C., MORISON, J., ZHANG, T., and BARRY, R.G. 2000. Observational evidence of recent change in the northern highlatitude environment. Climatic Change 46:159-207.

SHAPIRO, L.H. 1976. A preliminary study of ridging in landfast ice at Barrow, Alaska, using radar data. In: 3rd International Conference on Port Ocean Engineering, Arctic Conditions (POAC), held 11-15 August 1975, University of Alaska, Fairbanks. Vol. 1:417-425.

SHAPIRO, L.H., and METZNER, R.C. 1989. Nearshore ice conditions from radar data, Point Barrow area, Alaska. Geophysical Institute Reports, UAG-R(312). Fairbanks: University of Alaska. 43 p.

SPICHKIN, V.A. 1961. The mechanics of fast ice breakup (in Russian). Trudy - Arkticheskiy i Antarkticheskiy NauchnoIssledovatel'skiy Institut 256:12-27.

SQUIRE, V.A. 1993. The breakup of shore fast sea ice. Cold Regions Science and Technology 21(3):211-218.

STONEHOUSE, B. 1989. Polar ecology. London: Blackie. 222 p.

TUCKER, W.B., III, WEATHERLY, J.W., EPPLER, D.T., FARMER, D., and BENTLEY, D.L. 2001. Evidence for the rapid thinning of sea ice in the western Arctic Ocean at the end of the 1980s. Geophysical Research Letters 28(14):2851 - 2854.

WEEKS, W.F., and GOW, A. J. 1978. Preferred crystal orientations along the margins of the Arctic Ocean. Journal of Geophysical Research 83(C10):5105-5121.

WEEKS, W.F., KOVACS, A., MOCK, S.J., TUCKER, W.B., III, HIBLER, W.D., III, and GOW, A.J. 1977. Studies of the movement of coastal sea ice near Prudhoe Bay, Alaska, U.S.A. Journal of Glaciology 19(81):533-546.

WINSOR, P., and CHAPMAN, D.C. 2002. Distribution and interannual variability of dense water production from coastal polynyas on the Chukchi Shelf. Journal of Geophysical Research 107(C7):10.1029/2001JC000984. 